Chapman University

Chapman University Digital Commons

Education Faculty Articles and Research

College of Educational Studies

2014

\title{
Cultivating Primary Students' Scientific Thinking Through Sustained Teacher Professional Development
}

Roxanne Greitz Miller

Chapman University,rgmiller@chapman.edu

Margaret Sauceda Curwen

Chapman University, mcurwen@chapman.edu

Kimberly A. White-Smith

ChapmanUniversity, kwsmith@chapman.edu

Robert C. Calfee

Stanford University

Follow this and additional works at: http://digitalcommons.chapman.edu/education_articles

Part of the Curriculum and Instruction Commons, Elementary Education and Teaching Commons, Other Teacher Education and Professional Development Commons, and the Science and Mathematics Education Commons

\section{Recommended Citation}

Miller, R. G., Curwen, M. S., White-Smith, K. A. \& R. C. Calfee. (2014). Cultivating Primary Students' Scientific Thinking Through Sustained Teacher Professional Development. Early Childhood Education Journal, 43(4), 1-10. doi: 10.1007/s10643-014-0656-3

This Article is brought to you for free and open access by the College of Educational Studies at Chapman University Digital Commons. It has been accepted for inclusion in Education Faculty Articles and Research by an authorized administrator of Chapman University Digital Commons. For more

information, please contact laughtin@chapman.edu. 


\section{Cultivating Primary Students' Scientific Thinking Through Sustained Teacher Professional Development}

\section{Comments}

This is a pre-copy-editing, author-produced PDF of an article accepted for publication in Early Childhood Education Journal, volume 43, issue 4, in 2014 following peer review. The final publication is available at Springer via DOI: 10.1007/s10643-014-0656-3.

\section{Copyright}

Springer 


\title{
Cultivating primary students' scientific thinking through sustained teacher professional development
}

\author{
Roxanne Greitz Miller, Ed.D. \\ Chapman University \\ Margaret Sauceda Curwen, Ph.D \\ Chapman University \\ Kimberly A. White-Smith, Ed.D. \\ Chapman University \\ Robert C. Calfee, Ph.D. \\ Stanford University
}


Running Head: CULTIVATING PRIMARY STUDENTS’ SCIENTIFIC THINKING

\section{Cultivating primary students' scientific thinking through sustained teacher professional development}

\section{Introduction}

While the United States' National Research Council (NRC 2012) and Next Generation Science Standards (NGSS 2013) advocate children's engagement in active science learning, elementary grades teachers in the U.S. indicate they do not have enough time to teach science regularly because of pressure to focus on English language arts and mathematics - the subjects that constitute the largest weights in mandated assessments under the U.S Congress' No Child Left Behind (NCLB) Act of 2001 (FDR Research Group 2011). The result is science instruction has been reduced in, or eliminated from, many U.S. elementary classrooms, particularly in primary (Kindergarten-first-second) grades. Such is the case in the state of California (Dorph, Shields, Tiffany-Morales, Hartry, \& McCaffrey 2011), where our work is based.

While lessening focus on assessment results and providing adequate time for teaching science might seem an easy solution, many teachers in the Dorph et al. study (2011) report being under-prepared in science content knowledge and consequently hesitant to teach science even if time to do so existed. The U.S. National Research Council (NRC) asserts “...teachers need science-specific pedagogical content knowledge" (2012 p. 256) and, for busy practicing teachers, the main way they enhance their pedagogical knowledge is through professional development (PD). Budget cuts in California, as in many U.S. states, have significantly curtailed professional development, especially in science where eighty-five percent $(85 \%)$ of teachers surveyed reported not receiving science PD within the previous three years (Dorph et al. 2011 p. 40).

This exclusion of teacher PD in science content, and the teaching of science from 
elementary curricula, contributes to propagating intellectual poverty among students, particularly those experiencing economic poverty and for whom English is not their primary language, as they are often enrolled in schools facing greatest administrative pressure to narrow the curriculum (Jennings \& Renter 2006; Zwiep, Straits, Stone, Beltran, \& Furtado 2011). As a possible remedy to this problem, Project SMART (Science, Mathematics, Reading and Technology), a grant-based teacher professional development program, offered a research-based design aligned with Common Core State Standards' (CDE 2011) recommendations to teach science to young children in conjunction with literacy and mathematics, in order to increase instructional efficacy through integrated curriculum.

Project SMART was conducted over three school years in 13 schools within one midsized, urban public elementary school district in southern California. The study included 49 volunteer teachers and 1,535 students; $83 \%$ of these students participated in the federal lunch subsidy program and $62 \%$ were English learners. Teachers' years of experience ranged from one year to over 30; however, only $5 \%$ of the teachers held advanced degrees, far lower than the $40 \%$ average for other southern California districts. As part of a broader study on the project's impact, this article presents qualitative evidence from the teacher participants and examples illustrative of the integrated lessons teachers used. Teachers' comments provide insight that, through sustained professional development, they were able to increase their science content knowledge, overcome their hesitancy to teach science, and use integrated science-based instruction as a way to support primary grade students' learning.

\section{Meeting teachers' needs through effective science professional development}

When reviewing reform efforts, teachers are referred to as the "linchpin in any effort to change K-12 science education" (NRC 2012 p. 255) and, as such, their professional development 
is critical (Banilower, Heck, \& Weiss 2007; cf. NRC 2012). Opfer and Pedder's (2011) meta analysis summarizes that successful teacher PD attends to three interrelated and mutually informing "systems": the learning activity system (PD activities, their coherence, opportunities for reflection and time for supervised application of new learning), the teacher learning system (teacher's beliefs, values and perceptions) and the school/district systemic context (school practice, routine, and policies). Authentic teacher learning thrives when developed, implemented, and supported in all three interrelated systems. The Project SMART professional development program supported teachers in deepening their understanding of science content, addressed the additional conceptual and practical needs of the "teacher learning system and school/district systemic contexts" mentioned previously, and attempted to maximize influence on teacher practice by addressing social psychological factors as well. The ultimate goal of this integrated PD program approach was to impact: (1) teachers' science content knowledge, (2) science instructional time, and (3) instructional efficacy.

Project SMART addressed increasing teacher content knowledge by providing ongoing science PD by university science faculty: content area experts. "Adult" levels of science content related to the topics in K-2 science standards were presented; vertical and horizontal articulation was addressed so teachers at each grade level understood science content in grades below and above their own, as well within each grade. Social interaction was integrated into the science content lessons; teachers worked in cooperative groups across schools/grade levels to address social motivation and to increase interaction, thus creating a supportive collegial network.

Project SMART maintained that science instruction must begin in the primary grades and continue for all students in each subsequent grade level and used the Science-Cognition-Literacy (SCL) Framework model (Miller 2006; 2007; Figure 1) in an interdisciplinary manner (science, 
language arts, mathematics) to address the tension of limited instructional time and resources. An integrated curriculum was our deliberate response to structural limitations in U.S. schools and is consistent with the view that content knowledge is acquired simultaneously in multiple domains, and skills in literacy and mathematics are central to scientific understanding and communication.

Figure 1. Science-Cognition-Literacy Framework (Miller 2006).

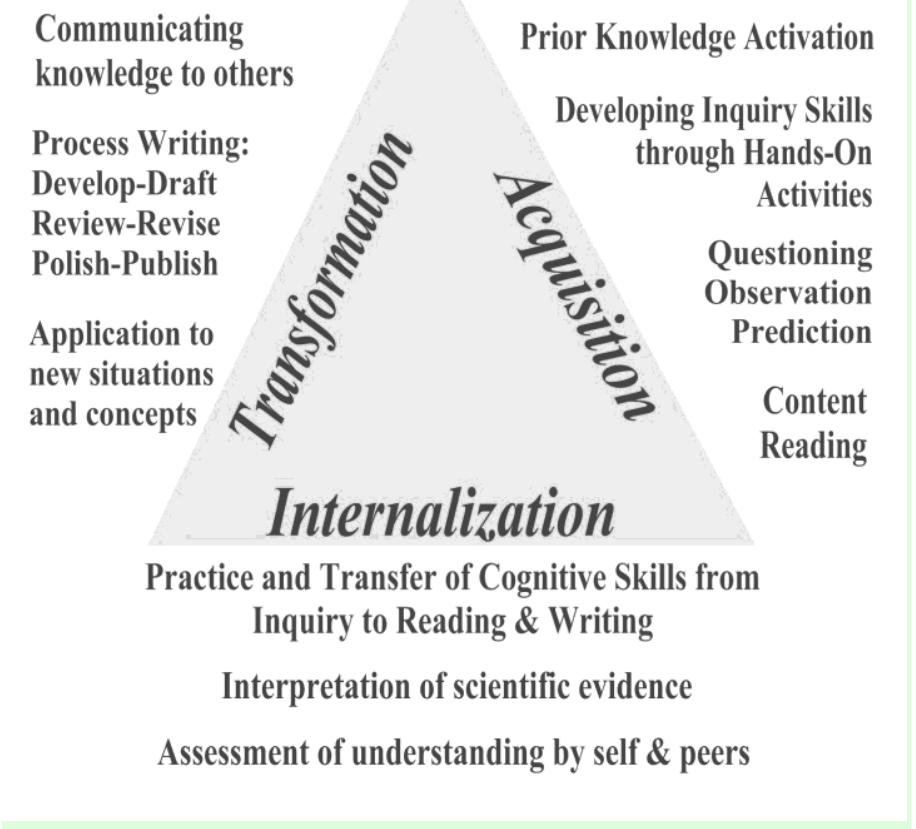

The three SCL Framework phases - acquisition, internalization, and transformation address essential constructivist elements of learning, consistent with research on integrating science and literary experiences (e.g., Chambliss and Calfee 1998; Guthrie, Wigfield, \& Von Secker 2000; Norris \& Phillips 2003; Miller 2007). University education faculty guided teachers through curriculum analysis of unifying themes, and taught them how to use science to teach literacy and mathematics standards, again lending horizontal and vertical coherence to the PD and addressing needs of teachers employed predominately in schools under sanctions to "stick" to teaching language arts and mathematics. Consistent with the characteristics of quality PD, teachers actively created their own interdisciplinary lesson plans - rather than being given 
"scripted lessons" - and collaborated with colleagues across grades and schools. Peer and research team observations of classroom teaching and reflection sessions provided feedback on new practice.

Teachers' need to concentrate on instructional efficiency was addressed through the integrated (science, math, reading) curriculum. The PD targeted three key science inquiry skills attainable by primary grade students - predicting, observing, and explaining (P-O-E) and developing teachers' pedagogical content knowledge. Teachers were involved in multiple handson science experiences focused on these three skills and on increasing student P-O-E capacity in science and reading and their predicting skill in mathematics. Teachers organized interdisciplinary science-literacy-mathematics lessons around P-O-E skills. The P-O-E organizing structure was mapped onto a Lesson Plan Template that classroom teachers used in planning and delivering integrated science and literary instruction. To provide for horizontal and vertical coherence, the research team extracted the "themes" of the district's basal reading series' units in grades $\mathrm{K}, 1$, and 2 and made explicit connections in the reading series to science and mathematics. During PD sessions and reciprocal peer coaching experiences over the three-year project, teachers reflected collaboratively on lessons' effectiveness; student knowledge was evaluated by the project team annually on an End-of-Year written science content assessment.

\section{Sample Unit and Focus}

To better understand the connections between the science content learned in the professional development sessions and the integration of the science, math, reading and technology in classroom instruction, we describe one of the units presented at the Kindergarten grades early in the school year. The theme found in the basal reading series was "Look at Us!" and contained readings where students learn about their personal characteristics, parts of the 
face, their hands, naming peoples' feelings based on their facial expressions and gestures, and using sensory words. This reading unit corresponded well with the science topic of the five senses, because of the explicit connections within the reading series to sensory words, and because we use our five senses to discover things about ourselves and the world around us. All three science inquiry terms at the center of the project - predict, observe, and explain - were relevant into this reading theme, because observations are made with our five senses.

In one presentation during the science PD, to enable teachers to better understand the sense of taste and its integration to additional senses (smell, touch), a university food scientist presented a lesson to teachers about the different types of taste buds and flavors that trigger reactions, going beyond the customary sweet/sour/bitter/salty and explained the interaction between smell and taste. "Mouth feel", the term that describes how food feels within the mouth, was also presented, and the effect of mouth feel on peoples' preferences for certain foods was explored and prompted engaging conversations about cultural differences. To connect math to the lessons, Kindergarten math concepts of identifying, counting, sorting and classifying were integrated into the PD activities and simple data tables were used to tally quantifiable data from observations, modeling how teachers could use these tables in their own lessons. As a technology extension, teachers were taught how to use USB temperature probes, and were shown how to use them in relevant ways, such as measuring the temperature of students' hands under different conditions, including inside a mitten, which corresponded to the ancillary children's book, The Mitten (Brett, 1989), used during this reading unit.

Resulting classroom science lessons included a "Lifesaver Lab" where students tasted different fruit flavor and mint candies with their noses closed and then open, marking on a simple data table their prediction beforehand if there would be any difference in taste, and then 
their observations and explanations; a sound activity where students predicted what sound would come from different size bottles when blown into or tapped, and then observed and explained their experiences; a math activity where students counted and classified the students in their class based on eye color; and a Sense Walk to be done at home, with students going through one room in their home and using sight, smell, and touch to observe at least 10 objects and having an adult write down their observations, to be shared later in class. (See Appendix for unit plan.)

\section{Teachers' Experiences}

To capture teacher pedagogical shifts and their evolving views on teaching, the following qualitative sources were collected: teacher interviews, classroom observations, surveys, journals, student artifacts, and comments from PD sessions. This section details findings from the end-ofproject Teacher Reflective Journal, in which teachers responded to prompts regarding changes in instructional practice, perceived student change, benefits and challenges of project participation, and future plans. Teacher comments were broken into smaller units using open coding (Strauss \& Corbin 1998) and analyzed by the research team. Key terms were identified and used to refine codes, e.g., words such as "afraid" and "fear" indicated prior perceptions of teaching science.

Four major strands among teacher quotes emerged, with findings triangulated through other data sources, including the research team's observations of classroom instruction and teacher interviews. Because teacher perspectives and skill were not necessarily aligned with years of teaching experience, we include years of experience here, categorized as: 0-5 years is beginner; 6-10 years is early career; 11-20 years is mid-career; and, 21+ years is late career.

\section{Listening to Teachers' Perspectives}

After three years of Project SMART professional development, primary grade teachers' shifts were evident in these four major strands: 1) confidence in and knowledge of science 
content; 2) perceived impact on student learning; 3) collaboration with peers in refining their teaching; and 3) perceptions of "permission" to teach science. (To best represent the teachers' voices and for ease of reading, teachers' emic language is italicized and included in quotations.) These four major strands were further analyzed for sub-categories and the findings are represented in each as depicted below in Table 1, with representative quotes.

Table 1. Qualitative Findings.

\begin{tabular}{|c|c|c|c|}
\hline Strand & Sub-categories & Frequency & $\begin{array}{l}\text { Example teacher comment and level of } \\
\text { teaching experience: }\end{array}$ \\
\hline \multirow{4}{*}{$\begin{array}{l}\text { Teacher } \\
\text { confidence } \\
\text { and } \\
\text { knowledge }\end{array}$} & $\begin{array}{l}\text { (a) Increased existing } \\
\text { science content } \\
\text { knowledge }\end{array}$ & 18 & $\begin{array}{l}\text { "Given me the tools to better teach the } \\
\text { science standards and thoroughly enjoy } \\
\text { each moment." (early career) }\end{array}$ \\
\hline & $\begin{array}{l}\text { (b) Increased } \\
\text { confidence as an } \\
\text { educator }\end{array}$ & 28 & $\begin{array}{l}\text { "[M] ost significant....is the } \\
\text { knowledge...to use science across the } \\
\text { curriculum." (mid-career) }\end{array}$ \\
\hline & $\begin{array}{l}\text { (c) Value of learning } \\
\text { from university } \\
\text { professors }\end{array}$ & 6 & $\begin{array}{l}\text { "We actually learned geology, } \\
\text { oceanography, physical, and life science." } \\
\text { (late career) }\end{array}$ \\
\hline & $\begin{array}{l}\text { (d) Previous lack of } \\
\text { science knowledge }\end{array}$ & 5 & $\begin{array}{l}\text { "[D]eveloped an interest [in science] that I } \\
\text { never had before." (beginner) }\end{array}$ \\
\hline \multirow{3}{*}{$\begin{array}{l}\text { Impact on } \\
\text { student } \\
\text { learning }\end{array}$} & $\begin{array}{l}\text { (a) Students' } \\
\text { academic growth }\end{array}$ & 19 & $\begin{array}{l}\text { "Science needs to be used in creating } \\
\text { thinkers for our future." (early career) }\end{array}$ \\
\hline & $\begin{array}{l}\text { (b) Science lessons as } \\
\text { engaging and } \\
\text { motivating }\end{array}$ & 8 & $\begin{array}{l}\text { "Science lessons became a prize, a } \\
\text { motivator for good behavior." (early } \\
\text { career) }\end{array}$ \\
\hline & $\begin{array}{l}\text { (c) Teachers' } \\
\text { epiphany on } \\
\text { practice }\end{array}$ & 6 & $\begin{array}{l}\text { "Perhaps one of the best outcomes was my } \\
\text { willingness to let the kids get their hands } \\
\text { dirty and figure things out for themselves." } \\
\text { (late career) }\end{array}$ \\
\hline $\begin{array}{l}\text { Learning } \\
\text { through } \\
\text { collaboration } \\
\end{array}$ & & 15 & $\begin{array}{l}\text { "...working together as a community } \\
\text { [helped our learning]" (mid-career) }\end{array}$ \\
\hline $\begin{array}{l}\text { Permission to } \\
\text { teach science }\end{array}$ & & 15 & $\begin{array}{l}\text { "I feel like I have been given the } \\
\text { permission to take the time to let students } \\
\text { enjoy experimentation and playing with } \\
\text { experiments." (mid-career) }\end{array}$ \\
\hline
\end{tabular}

\section{Increased confidence and science knowledge}

Related to increased confidence in the teaching of science, eight teachers used the terms 
"confidence" or "self-confidence" to indicate shifts toward including science pedagogy in their classrooms as a result of the PD experiences with content instruction, lesson ideas, and coherent ways of linking concepts to the district language arts, math, and science texts. This university support provided teachers tools to return to their classrooms with a "yearning to teach science" and with gained expertise. This notion was exemplified through one teacher's reflection on now being "confident when I teach science and students ask me questions," documenting impact on teachers' beliefs about themselves. Given that primary students range from five-year to eightyear-olds and have a natural sense of wonder, the teachers' ability to respond to children's curiosity is crucial. For some teachers, their lack of content knowledge previously resulted in relatively low comfort level in teaching science-even to the extent of one mid-career teacher's admission of being "afraid" to teach science before starting the PD. Through the project, teachers' use of materials and resources provided by the Project SMART facilitators, the district advisor, and science consultant, addressed such discomfort and provided a "safe" space to try new things and be supported in doing so.

In relation to science knowledge, evidentiary comments often used comparative terms (i.e., "greater" or "more") or temporal terms (i.e., "now" or "before") related to their content expertise. Several teachers indicated Project SMART refined their current knowledge by acquiring a "greater understanding" of scientific concepts. A mid-career educator recognized how the PD fortified her existing knowledge gaps by stating the Project "helped fill a lot of holes." Teachers voiced "more extensive understanding of basic scientific principles"; "[M]ost significant ...is the knowledge... to use science across the curriculum"; and, "[PD] gave me more thorough understanding of the different areas of science."

While many teachers viewed Project SMART's support in increasing their scientific 
knowledge, four individuals frankly remarked on their lack of science knowledge prior to participating in the project. Of particular note is one late career teacher who acknowledged the Project, "Has made me a much better science teacher...science knowledge was new to me." Teachers also shared a newfound affinity for science: "I never liked science when I was younger"; and, "[I've] developed an interest [in science] that I never had before."

Regarding the participation of science faculty as content experts, teachers related the caliber of instruction instrumental to their deep content learning. Two teachers even referred to the PD sessions as a "course" and "class/seminar/meeting." The following evidentiary quotes capture the credibility of university personnel whose instruction elevated the professional development from a typically brief one- or two-session teacher in-service to more robust and authentic learning experiences over time, another research-based identified aspect of successful PD (Desimone 2009): "We actually learned geology, oceanography, physical, and life science”; "The professors gave us background knowledge so I was confident when teaching my students."

\section{Impact on Student Learning}

The next major strand of the findings was how teachers perceived the impact of Project SMART on their students' learning, and therefore the ultimate teacher value of the PD experience. Teachers perceived teaching science was instrumental in shaping "well-rounded students" and also developing "critical thinkers."

An example of student learning through the predict-observe-explain science inquiry skills framework was captured in one Kindergarten class' extended unit, titled "Animals That Hatch", which was linked to the English language arts vocabulary and concept development from the district's basal reading series. As part of the prediction component, students recorded their thoughtful guesses on which animals might hatch from eggs through their illustrations and 
labeling on a circle Thinking Map® (see Photo 1). Over the next few weeks, students recorded their observations of the changes in live caterpillars and incubating duck eggs brought into the classroom. Further observational data was included in math lessons, as students categorized other animals that hatch from eggs and identified different types of birds, insects, and reptiles (see Photo 2). Children also counted and graphed the number of legs for several different animals. In the explain lesson component, students engaged in writing reports about different animals using the internet as a resource for additional information. This provided an opportunity for students to use the genre of report writing to construct a meaningful message and use conventions of grammar, capitalization, and punctuation. Students were scaffolded first by writing collaboratively in a group and then creating individual reports (see Photo 3).

\section{Photo 1. Prediction circle map on animals that hatch.}

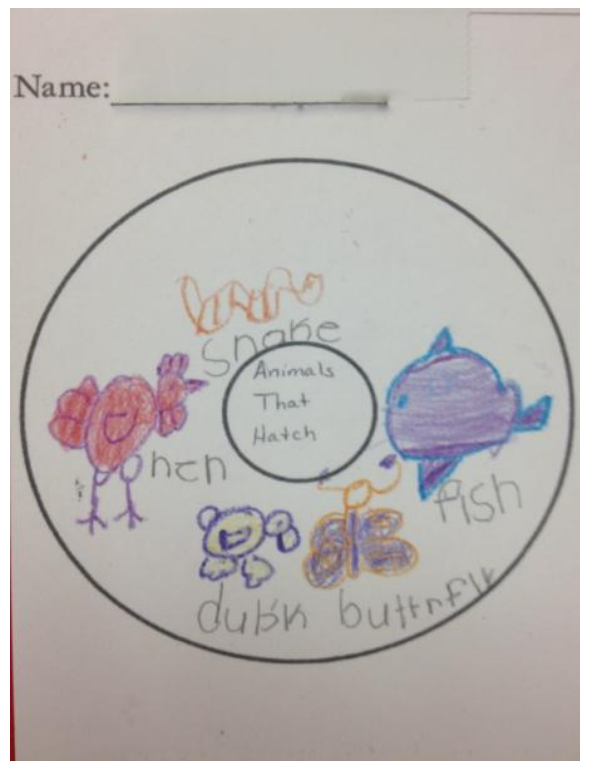

\section{Photo 2. Observation and classification of birds, insects and reptiles.}

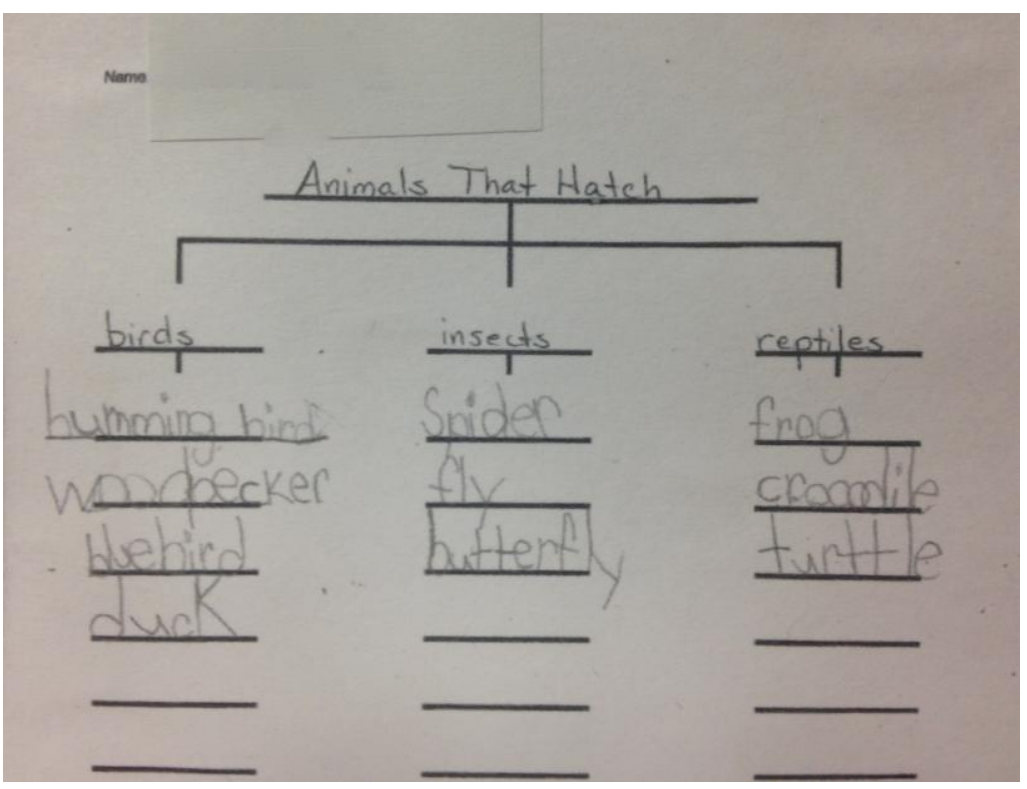




\section{Photo 3. Observe and explain report on Chrysalis.}

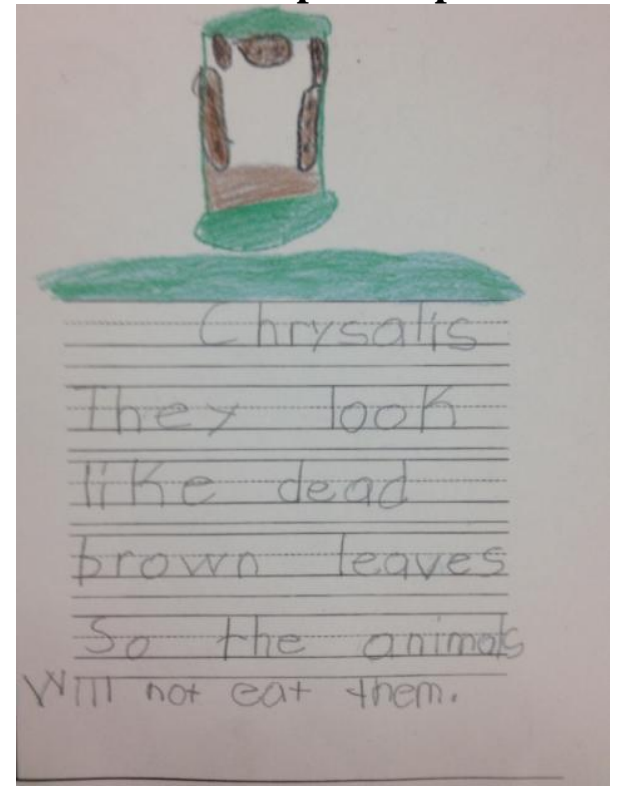

These teachers' pre-planning on linking science with math, language arts, and technology helped students conceive of their learning in a holistic manner. Because educational experiences shape the way individuals orient themselves to the world and "move through their world and act on it" (Rose 2012 p. 29), such student engagement has potential to motivate children (and teachers) to inculcate dispositions towards learning science early.

Upon integrating more science instruction, teachers recognized a change in their students' affect, noting the quality of questions and authentic engagement in the classroom. One teacher reported science was now a unifying element in her classroom. In her estimation, this inclusive aspect was vital for the English learners who were able to engage in the "universal language" of scientific exploration, thus ameliorating differences between cultural groups. These teacher comments were substantiated by numerous classroom observations in which children engaged in talking, listening, and documenting their scientific notations during hands-on science activities. It 
was not unusual for children to code-switch between English and Spanish to make peer learning more accessible.

Overall, teachers were pleased with students' response, as one teacher described surprise at continually finding evidence of students "thinking so outside of the box." For another teacher, project participation gave her the impetus to create a learner-centered classroom environment noting, "I have become aware of how important science is to my students." The teachers realized, upon observing their primary students' engagement, that teaching science was not an option but a necessity in the youngsters' school experiences.

\section{Learning through Peer Collaboration}

Teachers clearly valued becoming "a cohesive group" in their growth as science teachers (NRC 2012) and the social effect of the PD (Patterson et al. 2008). This collaboration occurred in three distinct ways. One aspect of shared learning took place during PD when teachers participated in "[science] experiments with other teachers." A second aspect was the manner in which teachers were provided time to discuss lesson plan design as a grade level team with other such teams across school sites, addressing the reflective element needed in PD (Opfer \& Pedder 2011). The third type of collaboration took place on school sites with peer observations and feedback, again centering on social motivation and ability (Patterson et al. 2008).

An example of such peer collaboration occurred among the second grade teachers during the second summer of PD. After receiving a science content lesson from university faculty on objects in motion one late career, one mid-career, and one beginner teacher formed a group and designed a collaborative lesson on ramps for their students (see Photo 4). The late career teacher took the role of English language development facilitator, and worked on the portion of the lesson where content-specific vocabulary would be front-loaded. The second teacher worked on 
the math and technology connections, deciding to offer students digital stopwatches to record the time it took for objects to travel down the ramp and rulers for students to be able to use the ramps as examples of triangles and measure them in centimeters. The third teacher handled the science portion of the lesson, discussing with students variables that effect motion (such as angle of ramp, friction, and gravity) and how the lesson would be presented in terms of the P-O-E skills (see Photo 5 for student work). Cooperatively, these teachers delivered the lesson during the summer PD to second grade students, with each teacher modeling for the other two her presentation style and format. This modeling supported these teachers when they independently replicated the entire lesson in their own classrooms during the regular school year.

Photo 4. Objects in Motion P-O-E lesson plan - Second Grade.

Topic: Objects in Motion

Standard(s): 1b: an objects motion can be recorded over time HM Theme 1 Silly Stories

HM Science Unit C Lesson 2 pages 174-181 Interactive Text pages

Materials: ramps, cars, meter sticks, recording sheet

PREDICT: How will you have students predict?

What do you predict will happen to the car as it travels down the ramps?

OBSERVE: How will you have students observe?

Ramps will be fixed at 3 different slopes/inclines. Students will roll a car down each ramp and record its distance.

EXPLAIN: How will you have students explain?

Students will record their data on a worksheet, engage in pair share and the class will create a multi-flow map (cause/effect). 


\section{Photo 5. Student work from Objects in Motion lesson.}

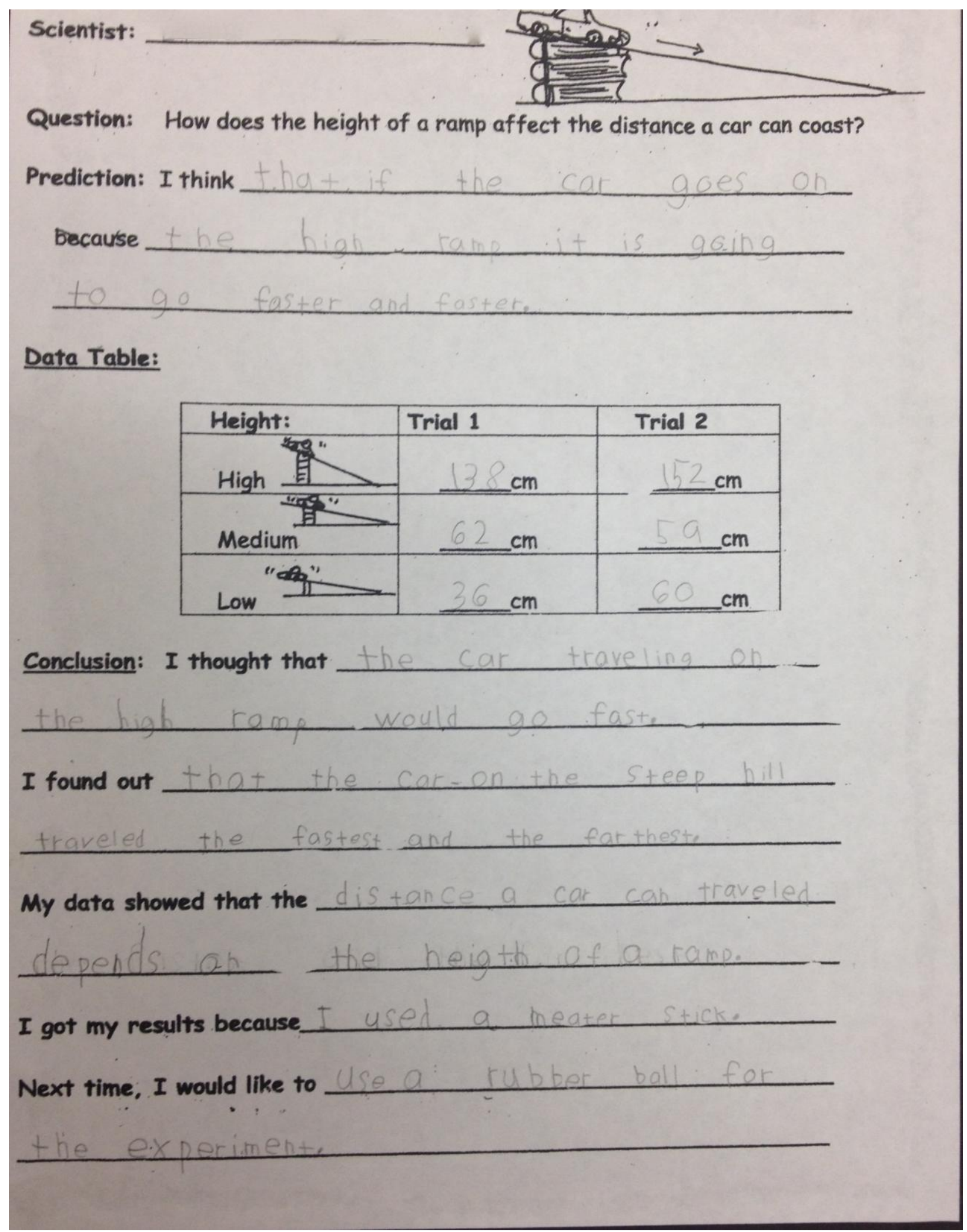


Running Head: CULTIVATING PRIMARY STUDENTS' SCIENTIFIC THINKING

One teacher noted the value of peer consultations such as this "enable[d] us to extend our lessons, improve our lessons, and [be] encouraged and supported [by] our peers." These teachers' statements reinforce the application of social psychology theory on social motivation and ability helping to sustain long-term change (Patterson et al. 2008).

\section{"Permission" to Teach Science}

Multiple teachers remarked participation in Project SMART gave them "permission" to teach science in their classrooms, thus removing structural barriers previously in place. It was somewhat surprising that more than a third of the 49 teachers' comments related to teachers' perception that the aegis of Project SMART provided an "excuse" to keep science instruction in their classroom. This finding is best explained by placing Project SMART within the national and local educational contexts. The No Child Left Behind (2001) national focus of accountability vis-à-vis standardized testing of exclusively English language arts and math in the elementary grades is reflected in this school district's focus. During formal interviews, teachers conceded that their schools' evaluations - and their own - were based almost exclusively on reading and math test scores. Consequently, teachers often attended only to the mandated testing areas of reading and math prior to the project.

Given this educational context, the teacher comments are more understandable. Teachers' remarks reflect their perception that by participating in Project SMART they had the authority and, as six teachers cited, the "permission," or freedom, to integrate science into the classroom. Unlike other typical PD where teachers might cite an additional burden of adding content to an overcrowded curriculum, these teachers were eager to provide time for science using the integrated method learned in PD. Their comments reflect a desire to seek out an "excuse to teach science." One teacher considered it "one of the [Project's] greatest gifts." Several teachers 
expressed earning a pedagogical privilege; a mid-career teacher declared, "Project SMART has given me the right to teach science" (emphasis in original). Teachers further commented that the Project "[H]as given me the allowance to teach science and not feel guilty..." and "I feel like I have been given the permission to take the time to let students enjoy experimentation and playing with experiments." After the project, teachers were able to demonstrate to administrators the positive impact of science on students' reading and math to legitimize continuing with regular science instruction after the project's end, but were faced with the district's overall achievement profile continuing to decline over time, with state sanctions on PD and instructional conformity across schools and classrooms becoming ever more prescriptive.

\section{Discussion}

The following discussion section addresses what we propose were the most important new “lessons learned about effective PD” from Project SMART and its impact on teachers' learning from university experts, peers, and their own students.

\section{Learning through Time and Trust Building}

Contemporary understandings of quality teacher professional development include attention to a variety of elements and perspectives; the process of developing teachers is increasingly recognized as a "complex system rather than an event" (Opfer \& Pedder 2011 p. 378; italics added). However, extended time is not only necessary for acquisition of deep content; it is necessary for trust building between all participants. Through an extended threeyear participation in Project SMART, teachers had opportunities to engage in PD that allowed them time to build trust between themselves as faculty from different schools, and with the university team. We believe attention to time and trust is necessary to assist teachers engaging in novel, and initially uncomfortable practices — such as peer observation of classroom practice- 
and in viewing PD providers as true partners in their efforts, and in obtaining honest feedback about teacher knowledge and practice during PD sessions.

\section{Learning from the Experts}

Participating teachers indicated the caliber of instruction provided by university science and education faculty was paramount to overcoming their trepidation in providing science instruction. Young children's ability to learn science is dependent on teachers' deep content knowledge and ability to convey information in developmentally appropriate ways (Banilower, Heck, \& Weiss 2007; NRC 2012). Without the requisite knowledge, teachers are constrained in developing scientific thinking and engagement, and, in our case, science content and pedagogy faculty were instrumental in assisting teachers to move their skills forward.

\section{Learning from One Another}

Teachers in Project SMART found the collaboration with peers highly significant. Often accustomed to working behind the closed doors of their individual classrooms and even more so within their own schools, Project SMART teachers gained facility in sharing their developing understanding with their peers across the district by collaborating on lesson planning and implementation. Through observation of peers' instruction and candid discussions after, teachers created an adult community of learners and a "shared understanding" of instruction and young children's science learning (NRC 2012 p. 246).

\section{Learning from Children}

The participating teachers in Project SMART provide evidence that young children flourish with active science education. Despite the high number of students in the Project who were English learners, virtually none of the participating teachers provided any indication that children had difficulty using scientific academic language and the Project's three key inquiry 
skills of predicting, observing, and explaining. Classroom observations by peers and by researchers provide further support for the proposition that the children in this California school district from diverse backgrounds, from low socio-economic communities, and who are English language learners, thrive in student-centered hands-on learning.

\section{Working Smarter}

Disturbingly, teachers in this study reported having little time to teach science, but did not instinctively turn to curriculum connections between science and other subjects as a natural way to include science in their instructional schedule, perhaps due to their prior lack of confidence or limited science content knowledge. Project SMART enabled teachers to create exemplary in which teachers taught science in conjunction with other subjects. It is clear that structural barriers need to be removed, or at least lessened, for teachers to feel they have "permission" to teach in this integrated manner, but this project shows rather clearly that integrated instruction at the primary grade levels can be effectively utilized to increase student knowledge and engagement in science.

\section{Closing Thoughts}

It is hoped that providing examples of successful, integrated approaches to long-term professional development and content instruction, like Project SMART, and sharing the voices of teachers who experience such involvement, will ultimately support changes in the way we approach teacher professional development and primary grades science instruction in the United States. Creating in young children the habits of mind that support content exploration and investigation, and in an integrated manner which capitalizes on all subject areas - language arts, science, and mathematics - simultaneously provides a way for children of diverse backgrounds to come together around a common scholastic endeavor and build their social capacities as well 
as content knowledge. However, we acknowledge that forces external to the classroom, most notably high-stakes assessment, which impose threats to such integrated approaches, must also be reformed for any type of lasting, systemic change to occur. Only when these external constraints are removed will our primary grades teachers truly have the "right" to teach science and cultivate primary students' scientific thinking, as they so clearly communicated they were able to do within this project.

\section{Acknowledgements}

This research was funded by the Improving Teacher Quality State Grants Program (Award 07412) of the California Postsecondary Education Commission. 


\section{References}

Banilower, E.R., Heck, D.J., \& Weiss, I.R. (2007). Can professional development make the vision of the standards a reality? The impact of the National Science Foundation's Local Systemic Change through Teacher Enhancement Initiative. Journal of Research in Science Teaching, 44(3), 375-395.

California Department of Education (CDE). (2011) A Look at Kindergarten in California Public Schools and the Common Core State Standards. Downloaded from http://www.cde.ca.gov/ci/cr/cf/documents/glckindercurriculum.pdf

Chambliss, M.J., \& Calfee, R.C. (1998). Textbooks for learning: Nurturing children's minds. Malden, MA: Blackwell.

Desimone, L.M. (2009). Improving impact studies of teachers' professional development: Toward better conceptualizations and measures. Educational Researcher, 38(3), 181-199.

Dorph, R., Shields, P., Tiffany-Morales, J., Hartry, A., \& McCaffrey, T. (2011). High hopesFew opportunities: The status of elementary science education in California. Sacramento, CA: The Center for the Future of Teaching and Learning at WestEd. Retrieved 10-21-11 from http://www.cftl.org/documents/2011/StrengtheningScience full.pdf

FDR Research Group, 2011. Learning Less: Public School Teachers Describe a Narrowing Curriculum. Published December 8, 2011.

Guthrie J., Wigfield, A., \& Von Secker, C. (2000). Effects of integrated instruction on motivation and strategy use in reading. Journal of Educational Psychology, 92(2), 331341.

Jennings, J., \& Renter, D. S. (2006). The Big Effects of the No Child Left Behind Act on Public Schools. Phi Delta Kappan, 88(2), 110-113.

Miller, R.G. (2006). Unlocking reading comprehension with key science inquiry skills. Science Scope, 30(1), 30-33.

Miller, R.G. (2007). Thinking like a scientist: Exploring transference of science inquiry skills to literacy applications with kindergarten students. Electronic Journal of Literacy Through Science, 6(1), 41-53.

National Research Council (2012). A framework for K-12 science education: Practices, crosscutting concepts, and core ideas. Committee on a Conceptual Framework for New K-12 Science Education Standards. Board on Science Education, Division of Behavioral and Social Sciences and Education Washington, DC: The National Academies Press. Retrieved from: www.nap.edu/catalog.php?record_id=13165

Next Generation Science Standards (NGSS). (2013, April). Conceptual Shifts in the Next Generation Science Standards, page 5. Downloaded from: http://www.nextgenscience.org/sites/ngss/files/Appendix\%20A\%20- 


\section{\%204.11.13\%20Conceptual\%20Shifts\%20in\%20the\%20Next\%20Generation\%20Scienc} e\%20Standards.pdf

Norris, S. P., \& Phillips, L. M. (2003). How literacy in its fundamental sense is central to scientific literacy. Science Education, 87, 224-240.

Opfer, V. D., \& Pedder, D. (2011). Conceptualizing teacher professional learning. Review of Educational Research, 81(3). 376-407.

Patterson, K., Grenny, J., Maxfield, D., MacMillan, R. \& Switzler, A. (2008). Influencer: The power to change anything. New York: McGraw Hill.

Rose, M. (2012). Back to school: Why everyone deserves a second chance at education. New York: The New Press.

Strauss, A., \& Corbin, J. (1998). Basics of qualitative research. Thousand Oaks, CA: Sage.

U.S. Congress. (2001). No child left behind act of 2001. Public Law 107-110. 107th Congress. Washington, DC: Government Printing Office.

Zwiep, S. G., Straits, W. J., Stone, K., Beltran, D., \& Furtado, L. (2011). The integration of English language development and science instruction in elementary classrooms. Journal of Science Teacher Education, 22(8), 769-785.

Texts cited:

Brett, Jan (1989). The Mitten. G.P. Putnam's Sons. New York. 
Appendix A. Sample Kindergarten Unit

\begin{tabular}{|c|c|c|}
\hline READING THEME & \multicolumn{2}{|l|}{ Look at Us! } \\
\hline SMART THEME & \multicolumn{2}{|c|}{$\begin{array}{l}\text { Thinking Like a Scientist: Scientists predict, observe, and explain. Good } \\
\text { readers and writers also predict, observe, and explain. While reading the } \\
\text { stories, you will practice these three skills all year long. }\end{array}$} \\
\hline $\begin{array}{l}\text { PREDICT-OBSERVE- } \\
\text { EXPLAIN EMPHASIS }\end{array}$ & \multicolumn{2}{|c|}{$\begin{array}{l}\text { Students will be able to (SWBAT) demonstrate basic prediction, } \\
\text { observation, \& explanation skills. }\end{array}$} \\
\hline $\begin{array}{l}\text { SCIENCE } \\
\text { STANDARDS }\end{array}$ & \multicolumn{2}{|c|}{$\begin{array}{l}\text { Physical Science: Describe objects. } \\
\text { Life Science: compare plants/animals; know fantasy/real plants/animals. } \\
\text { Investigation \& Experimentation: Observe objects using } 5 \text { senses; } \\
\text { describe common objects; describe object's position; compare \& sort } \\
\text { objects; communicate observations. }\end{array}$} \\
\hline MATH STANDARDS & \multicolumn{2}{|c|}{$\begin{array}{l}\text { Number Sense: Compare two or more sets; count, recognize, represent, } \\
\text { name, and order; larger numbers describe sets with more objects } \\
\text { Addition: Identify, sorts and classify objects by attribute } \\
\text { Measurement: Compare the length, weight and capacity of objects; } \\
\text { understanding of concepts of time; identify and describe common } \\
\text { geometric objects; compare familiar objects by common attributes } \\
\text { Statistics: Pose information Qs; collect data; record the results; identify, } \\
\text { describe, and extend simple patterns } \\
\text { Math Reasoning: Determine the approach, materials, and strategies; use } \\
\text { tools and strategies; explain the reasoning used; make precise } \\
\text { calculations and check validity }\end{array}$} \\
\hline $\begin{array}{l}\text { SCIENCE BASAL } \\
\text { TEXT ACTIVITIES }\end{array}$ & $\begin{array}{ll}\text { - } & 5 \text { senses } \\
\text { - } & \text { Sorting/classifying objects }\end{array}$ & $\begin{array}{l}\text { - Observing properties: Sink or } \\
\text { float } \\
\text { - Observing magnetic properties }\end{array}$ \\
\hline TECH ACTIVITIES & \multicolumn{2}{|c|}{$\begin{array}{l}\text { - Learning to Use Go!Temp-Observe the temperature of different } \\
\text { objects; explain differences. } \\
\text { - Are We Cool or What? - Predict, observe changing temperature of } \\
\text { childrens' hands under different conditions; explain differences. } \\
\text { - Why Do We Need Thermometers? - Determine if touch is adequate } \\
\text { to measure temperature; explain the need for a thermometer. }\end{array}$} \\
\hline $\begin{array}{l}\text { ADDITIONAL } \\
\text { HANDS-ON } \\
\text { ACTIVITIES }\end{array}$ & \multicolumn{2}{|c|}{$\begin{array}{l}\text { 1. Based on photographs of their families, SWBAT predict what they } \\
\text { might look like as adults and explain why. } \\
\text { 2. Lifesaver Lab: SWBAT predict how fruit and mint lifesavers will } \\
\text { taste with nose open \& closed, observe by testing, and explain results. } \\
\text { 3. Colorful Eyes: Students P-O-E eye color found most frequently } \\
\text { among children in the classroom. } \\
\text { 4. Sound is Vibrations: Students P-O-E sounds of different size bottles. } \\
\text { 5. We Need } 5 \text { Senses: SWBAT explain that they obtain more } \\
\text { information if the use more than one sense to identify substances. } \\
\text { 6. How Close Can You Get: Students explain how stimuli are perceived } \\
\text { differently on different areas of the body. }\end{array}$} \\
\hline $\begin{array}{l}\text { RELATED } \\
\text { READINGS }\end{array}$ & \multicolumn{2}{|l|}{ The Mitten (Brett, 1989) } \\
\hline AT HOME IDEAS & \multicolumn{2}{|c|}{$\begin{array}{l}\text { Sense walk: Students go through one room in their home and using } \\
\text { sight, smell, and touch they observe at least } 10 \text { objects in the room and } \\
\text { have an adult write down their observations. }\end{array}$} \\
\hline
\end{tabular}

